\title{
Risk factors of embolism for the cardiac myxoma patients: a systematic review and metanalysis
}

\author{
Yanna Liu, Jiwei Wang, Liangyun Guo and Luyi Ping *i]
}

\begin{abstract}
Background: The risk factors contributing to embolism in cardiac myxoma (CM) are yet controversial. This systematic review and meta-analysis aimed to clarify the risk factors of embolism for the CM patients.

Methods: PubMed, Embase, Cochrane library, Web of Science, China National Knowledge Infrastructure, Wan Fang, and Wei Pu databases were searched from inception to June 2019. Statistical analysis was conducted using Stata version 14.0. The pooled odds ratio or mean difference with $95 \%$ confidence interval was estimated for each risk factor.

Results: Herein, 12 studies, encompassing 1814 patients, were included. The pooled results suggested that New York Heart Association (NYHA) class I/II $(P<0.01)$, hypertension $(P=0.03)$, irregular tumor surface $(P<0.01)$, tumor in atypical location $(P=0.01)$, narrow base of tumor $(P<0.01)$, and increased fibrinogen (FIB) $(P<0.01)$ are significant risk factors of embolism in CM patients. However, sex, age, body mass index, smoking, left ventricular ejection fraction, diabetes, hyperlipidemia, atrial fibrillation, valvular heart disease, coronary heart disease, tumor size, platelet count, white blood cells, and hemoglobin were not associated with embolism (all $P>0.05$ ).

Conclusions: NYHA class (I/II), hypertension, irregular tumor surface, atypical tumor location, the narrow base of tumor, and increased FIB were significant risk factors of embolism in CM patients. For CM patients with these factors, early surgery might be beneficial to prevent embolism.
\end{abstract}

Keywords: Cardiac myxoma, Embolism, Risk factors, Meta-analysis

\section{Background}

Cardiac myxomas (CMs) are the most prevalent type of primary cardiac tumors in adults [1] that account for approximately half of all benign lesions. The manifestations of CM patients include obstruction, preoperative embolization, and constitutional symptoms. Embolization is a major and fatal complication that occurs in $20-45 \%$ of CM patients [2]; it includes cerebral embolism and peripheral embolism. Cerebral embolism accounts for about $50 \%$ of the embolic events, mainly

\footnotetext{
* Correspondence: 939684026@qq.com

Department of Ultrasound, The Second Affiliated Hospital of Nanchang University, Minde Road No.1, Nanchang 330006, Jiangxi, China
}

acute stroke symptoms. Peripheral embolism may involve extremity, visceral, and coronary arteries [3]. The right-sided CMs are associated with pulmonary embolism. These embolic events are significant causes of mortality in CM patients [4]; however, the exact factors related to the occurrence of embolism are not yet clearly identified.

Although, several risk factors of embolism are recently reported [5-16], some are controversial. For instance, a previous study [17] showed that the small size of the tumor was an independent risk factor for embolism, whereas other studies neither found any association [14] nor presented a contrary conclusion [13]. Some studies

(c) The Author(s). 2020 Open Access This article is licensed under a Creative Commons Attribution 4.0 International License, which permits use, sharing, adaptation, distribution and reproduction in any medium or format, as long as you give appropriate credit to the original author(s) and the source, provide a link to the Creative Commons licence, and indicate if changes were made. The images or other third party material in this article are included in the article's Creative Commons licence, unless indicated otherwise in a credit line to the material. If material is not included in the article's Creative Commons licence and your intended use is not permitted by statutory regulation or exceeds the permitted use, you will need to obtain permission directly from the copyright holder. To view a copy of this licence, visit http://creativecommons.org/licenses/by/4.0/ The Creative Commons Public Domain Dedication waiver (http://creativecommons.org/publicdomain/zero/1.0/) applies to the data made available in this article, unless otherwise stated in a credit line to the data. 


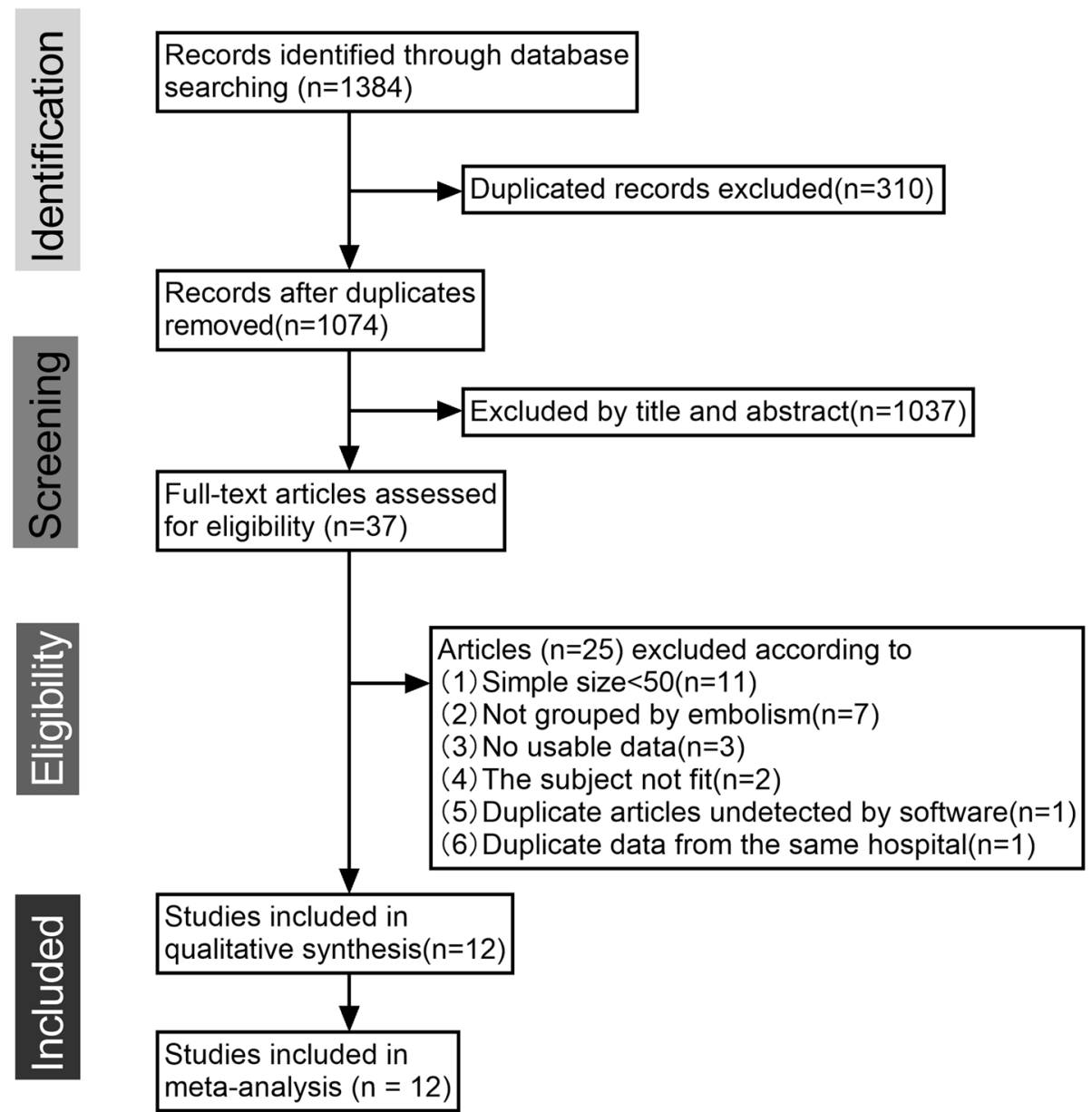

Fig. 1 Flowchart of study selection

reported that the male gender was associated with an increased risk of embolism [18], while others failed to find this association [6, 7]. Therefore, we conducted this systematic review with meta-analysis to clarify the risk factors of embolism in CM patients.

\section{Methods}

Data sources and search strategy

The Preferred Reporting Items for Systematic Reviews and Meta-Analyses statement was followed [19]. The PubMed, Embase, Cochrane library, Web of Science, China National Knowledge Infrastructure, Wan Fang, and Wei Pu databases were used for further studies. The search strings are reported in Additional file 1. Studies published up to June 30, 2019, were eligible. No language restriction was applied. Reference lists of selected studies were checked to ensure complete coverage.

\section{Eligibility criteria}

The studies that fulfilled the following criteria were eligible for inclusion in this meta-analysis: 1) All CM patients who underwent surgical resection and were confirmed by pathological examination; 2) Patients in each study were classified into two groups (embolic and non-embolic); 3) Embolic events were diagnosed by clinical symptoms or imaging examination. If the same population was presented in more than one publication, the study with the largest sample was included.

We excluded the studies that met at least one of the following criteria: 1) Sample size < 50; 2) Abstracts from conferences, letters to the editor, and reviews; 3 ) Incomplete data.

\section{Data extraction and quality assessment}

Two authors (L.P and J.W) reviewed all retrieved articles and extracted data independently. The titles and abstracts were first screened to identify potentially eligible articles, and then, full texts were read to confirm their eligibility for inclusion in this meta-analysis. The extracted data included the following information: first author, year of publication, country, study type, sample size, age, incidence of embolism, and risk factors that 
Table 1 Characteristics of included studies

\begin{tabular}{|c|c|c|c|c|c|c|c|c|c|}
\hline \multirow[t]{2}{*}{ study } & \multirow[t]{2}{*}{ country } & \multirow[t]{2}{*}{ type of study } & \multicolumn{2}{|l|}{ sample size } & \multicolumn{2}{|c|}{$\begin{array}{l}\text { age }(M e a n \pm S D \text { or } \\
\text { median(IQR)) }\end{array}$} & \multirow{2}{*}{$\begin{array}{l}\text { incidence } \\
\text { of } \\
\text { embolism }\end{array}$} & \multirow[t]{2}{*}{ risk factors } & \multirow[t]{2}{*}{$\begin{array}{l}\text { the JBI Appraisal } \\
\text { Checklist }\end{array}$} \\
\hline & & & $\begin{array}{l}\text { embolisim } \\
\text { group }\end{array}$ & $\begin{array}{l}\text { non- } \\
\text { embolism } \\
\text { group }\end{array}$ & $\begin{array}{l}\text { embolisim } \\
\text { group }\end{array}$ & $\begin{array}{l}\text { non- } \\
\text { embolism } \\
\text { group }\end{array}$ & & & \\
\hline $\begin{array}{l}\text { Cao } 2017 \\
{[5]}\end{array}$ & China & $\begin{array}{l}\text { Retrospective } \\
\text { case series }\end{array}$ & 24 & 87 & $36.0 \pm 8.1$ & $36.4 \pm 6.5$ & $21.62 \%$ & tumor size & $\begin{array}{l}\text { yes(6)no(3)unclear(1) } \\
\text { not applicable(0) }\end{array}$ \\
\hline $\begin{array}{l}\text { Deng } 2015 \\
\text { [6] }\end{array}$ & China & $\begin{array}{l}\text { Retrospective } \\
\text { case series }\end{array}$ & 33 & 129 & $48(38-61)$ & $54(46-63)$ & $20.37 \%$ & $\begin{array}{l}\text { tumor location, tumor } \\
\text { surface, MPV, PLT }\end{array}$ & $\begin{array}{l}\text { yes(8)no(1)unclear(1) } \\
\text { not applicable(0) }\end{array}$ \\
\hline $\begin{array}{l}\text { Lee } 2012 \\
{[7]}\end{array}$ & Korea & $\begin{array}{l}\text { Retrospective } \\
\text { case series }\end{array}$ & 13 & 46 & $59.2 \pm 12.6$ & $58.3 \pm 12.6$ & $22.03 \%$ & tumor surface & $\begin{array}{l}\text { yes(7)no(2)unclear(1) } \\
\text { not applicable(0) }\end{array}$ \\
\hline $\begin{array}{l}\text { Wang } 2016 \\
\text { [8] }\end{array}$ & China & $\begin{array}{l}\text { Retrospective } \\
\text { case series }\end{array}$ & 32 & 175 & $39.7 \pm 16.6$ & $45.0 \pm 15.5$ & $15.46 \%$ & $\begin{array}{l}\text { tumor size, tumor } \\
\text { surface }\end{array}$ & $\begin{array}{l}\text { yes(7)no(2)unclear(1) } \\
\text { not applicable(0) }\end{array}$ \\
\hline $\begin{array}{l}\text { Yin } 2016 \\
{[9]}\end{array}$ & China & $\begin{array}{l}\text { Retrospective } \\
\text { case series }\end{array}$ & 143 & 322 & $59.4 \pm 10.9$ & $52.3 \pm 12.4$ & $44.41 \%$ & $\begin{array}{l}\text { age, BMI, tumor size, } \\
\text { tumor surface, tumor } \\
\text { location, LAD CHA2DS2- } \\
\text { VASc score }\end{array}$ & $\begin{array}{l}\text { yes(8)no(1)unclear(1) } \\
\text { not applicable(0) }\end{array}$ \\
\hline Li 2018 [10] & China & $\begin{array}{l}\text { Retrospective } \\
\text { case series }\end{array}$ & 27 & 158 & $\begin{array}{l}48.19 \pm \\
13.11\end{array}$ & $\begin{array}{l}49.39 \pm \\
14.97\end{array}$ & $14.59 \%$ & $\begin{array}{l}\text { tumor location,tumor } \\
\text { base size, FIB }\end{array}$ & $\begin{array}{l}\text { yes(7)no(2)unclear(1) } \\
\text { not applicable(0) }\end{array}$ \\
\hline $\begin{array}{l}\text { Xu } 2016 \\
{[11]}\end{array}$ & China & $\begin{array}{l}\text { Retrospective } \\
\text { case series }\end{array}$ & 26 & 156 & $\begin{array}{l}58.54 \pm \\
12.65\end{array}$ & $\begin{array}{l}57.29 \pm \\
11.11\end{array}$ & $14.29 \%$ & $\begin{array}{l}\text { tumor surface, tumor } \\
\text { base size, FIB }\end{array}$ & $\begin{array}{l}\text { yes(8)no(1)unclear(1) } \\
\text { not applicable(0) }\end{array}$ \\
\hline $\begin{array}{l}\text { Boyacıoğlu } \\
2017 \text { [12] }\end{array}$ & Turkey & $\begin{array}{l}\text { Retrospective } \\
\text { case series }\end{array}$ & 25 & 74 & $49 \pm 16.89$ & $\begin{array}{l}50.12 \pm \\
15.71\end{array}$ & $25.26 \%$ & $\begin{array}{l}\text { AF, tumor surface, tumor } \\
\text { size }\end{array}$ & $\begin{array}{l}\text { yes(7)no(2)unclear(1) } \\
\text { not applicable(0) }\end{array}$ \\
\hline $\begin{array}{l}\text { Kalçık } 2019 \\
{[13]}\end{array}$ & Turkey & $\begin{array}{l}\text { Retrospective } \\
\text { case series }\end{array}$ & 13 & 80 & $50(36-62)$ & $56(45-65)$ & $13.98 \%$ & $\begin{array}{l}\mathrm{LAD}, \mathrm{AF} \text {, tumor size, } \\
\text { tumor surface }\end{array}$ & $\begin{array}{l}\text { yes(7)no(2)unclear(1) } \\
\text { not applicable(0) }\end{array}$ \\
\hline $\begin{array}{l}\text { Ping } 2019 \\
\text { [14] }\end{array}$ & China & $\begin{array}{l}\text { Retrospective } \\
\text { case series }\end{array}$ & 32 & 75 & $\begin{array}{l}54.66 \pm \\
13.21\end{array}$ & $\begin{array}{l}51.72 \pm \\
13.76\end{array}$ & $29.91 \%$ & $\begin{array}{l}\text { tumor surface, tumor } \\
\text { location }\end{array}$ & $\begin{array}{l}\text { yes(7)no(2)unclear(1) } \\
\text { not applicable(0) }\end{array}$ \\
\hline $\begin{array}{l}\text { Canga } \\
2017[15]\end{array}$ & Turkey & $\begin{array}{l}\text { Retrospective } \\
\text { case series }\end{array}$ & 13 & 53 & $51.1 \pm 11.4$ & $55.9 \pm 12.4$ & $19.70 \%$ & $\begin{array}{l}\text { sex,tumor location,tumor } \\
\text { surface }\end{array}$ & $\begin{array}{l}\text { yes(7)no(2)unclear(1) } \\
\text { not applicable(0) }\end{array}$ \\
\hline $\begin{array}{l}\text { Zheng } \\
2014 \text { [16] }\end{array}$ & China & $\begin{array}{l}\text { Retrospective } \\
\text { case series }\end{array}$ & 15 & 63 & $49 \pm 9$ & $52 \pm 6$ & $19.23 \%$ & tumor surface & $\begin{array}{l}\text { yes(7)no(2)unclear(1) } \\
\text { not applicable(0) }\end{array}$ \\
\hline
\end{tabular}

SD: standard deviation IQR: interquartile range LAD: left atrium diameter the CHA2DS2-VASC: congestive heart failure, hypertension, age $\geq 75$ (doubled), diabetes, stroke(doubled), vascular disease, age 65-74, and sex category (female) recommended by European Society of Cardiology (ESC) is an easy-to-remember means of assessing stroke risk of patients with AF

include patient characteristics (sex, age, New York Heart Association (NYHA) class and atrial fibrillation (AF)), tumor characteristics (tumor surface and tumor location), and hematological parameters (white blood cell (WBC) and platelet count (PLT)). The NYHA class was divided into two groups (I/II vs. III/IV). The tumor surface was classified as irregular and regular [7]. The tumor location was classified into "typical location" (tumor arise from the interatrial septum at the border of the fossa ovalis in the left atrium) and "atypical location" (tumor arise from other sites of the left atrium or in the other cardiac chambers) [20]. The extracted data were cross-checked, and any disagreements were resolved by discussion or consultation with the third author (L.G).

The quality of the included studies was assessed using the Joanna Briggs Institute (JBI) Critical Appraisal Checklist [21] for Case Series. It contains ten items, encompassing clear criteria for inclusion, the information of participants, and the statistical methods used. Each item was determined by yes, no, unclear, and not applicable.

\section{Statistical analysis}

Stata 14.0 was used for the statistical analysis of all data. The odds ratio/mean difference (OR/MD) and 95\% confidence interval $(\mathrm{CI})$ were calculated using the fixedeffect model or the random effect model. The heterogeneity among studies was quantified using the Cochran's Q test and chi-square $\left(\mathrm{I}^{2}\right)$ test. $\mathrm{I}^{2}=25 \%$ was considered low, $50 \%$ was moderate, and $75 \%$ was high. When $\mathrm{I}^{2}>50 \%$ or $P$-value $<0.05$ was identified for substantial heterogeneity, we used the random effect model; otherwise, a fixed-effect model was adopted. A sensitivity analysis was conducted when substantial heterogeneity was presented. Publication bias was assessed by the Egger's test. All tests were two-sided, and the results were considered statistically significant at $P<0.05$.

\section{Results}

Search results and characteristics of included studies

A total of 12 studies [5-16] encompassing 1814 patients who underwent surgery with $\mathrm{CM}$ were selected for the current analysis. The detailed study selection progress is 
Table 2 Main characteristics of each risk factor

\begin{tabular}{|c|c|c|c|c|c|c|c|}
\hline Risk Factors & No. Studies & Effect Model & $1^{2}, \%$ & $P h$ & MD/OR & Effect Size $(95 \%$ Cl) & $P$ \\
\hline sex(male) & 12 & $\mathrm{~F}$ & 16.8 & 0.28 & OR & $1.21(0.96-1.53)$ & 0.11 \\
\hline age & 9 & R & 76.8 & $<0.01$ & MD & $-0.04(-3.64-3.56)$ & 0.94 \\
\hline BMI & 4 & $R$ & 83.7 & $<0.01$ & MD & $1.21(-0.43-2.84)$ & 0.18 \\
\hline NYHA class(I/II) & 4 & $\mathrm{~F}$ & 0.0 & 0.61 & OR & $2.98(1.66-5.33)$ & $<0.01^{*}$ \\
\hline smoking & 6 & $\mathrm{~F}$ & 0.0 & 0.44 & OR & $0.90(0.64-1.28)$ & 0.56 \\
\hline LVEF & 6 & $\mathrm{~F}$ & 7.0 & 0.37 & MD & $0.59(-0.20-1.38)$ & 0.14 \\
\hline hypertension & 8 & $\mathrm{~F}$ & 0.1 & 0.43 & OR & $1.41(1.04-1.92)$ & $0.03^{*}$ \\
\hline diabetes & 8 & $\mathrm{~F}$ & 0.0 & 0.73 & OR & $1.32(0.89-1.94)$ & 0.16 \\
\hline hyperlipidemia & 6 & $\mathrm{~F}$ & 0.0 & 0.79 & OR & $0.99(0.53-1.85)$ & 0.96 \\
\hline atrial fibrillation & 7 & $\mathrm{~F}$ & 48.5 & 0.07 & OR & $1.25(0.88-1.80)$ & 0.22 \\
\hline valvular heart disease & 3 & $\mathrm{~F}$ & 0.0 & 0.62 & OR & $0.76(0.41-1.40)$ & 0.38 \\
\hline coronary heart disease & 3 & R & 84.2 & $<0.01$ & OR & $0.99(-0.87-2.85)$ & 0.32 \\
\hline tumor surface(irregular) & 11 & $\mathrm{~F}$ & 40.4 & 0.08 & OR & $3.99(3.04-5.25)$ & $<0.01^{*}$ \\
\hline tumor size & 8 & R & 83.3 & $<0.01$ & $M D$ & $-0.10(-0.76-0.57)$ & 0.78 \\
\hline tumor location(atypical) & 4 & $\mathrm{~F}$ & 15.9 & 0.31 & OR & $1.81(1.13-2.88)$ & $0.01^{*}$ \\
\hline tumor base size & 2 & $\mathrm{~F}$ & 0.0 & 0.66 & $M D$ & $-0.36(-0.51--0.22)$ & $<0.01^{*}$ \\
\hline PLT & 3 & $\mathrm{~F}$ & 0.0 & 0.83 & MD & $9.95(-6.02-25.91)$ & 0.22 \\
\hline WBC & 4 & $\mathrm{~F}$ & 34.6 & 0.21 & $M D$ & $0.18(-0.33-0.68)$ & 0.49 \\
\hline$H B$ & 4 & $\mathrm{~F}$ & 0.0 & 0.40 & MD & $1.65(-2.91-6.21)$ & 0.48 \\
\hline $\mathrm{FIB}$ & 2 & $\mathrm{~F}$ & 0.0 & 0.57 & MD & $0.62(0.28-0.95)$ & $<0.01^{*}$ \\
\hline
\end{tabular}

F: fixed-effects model R: random-effects model Ph: $P$ value of heterogeneity ${ }^{*} P<0.05$

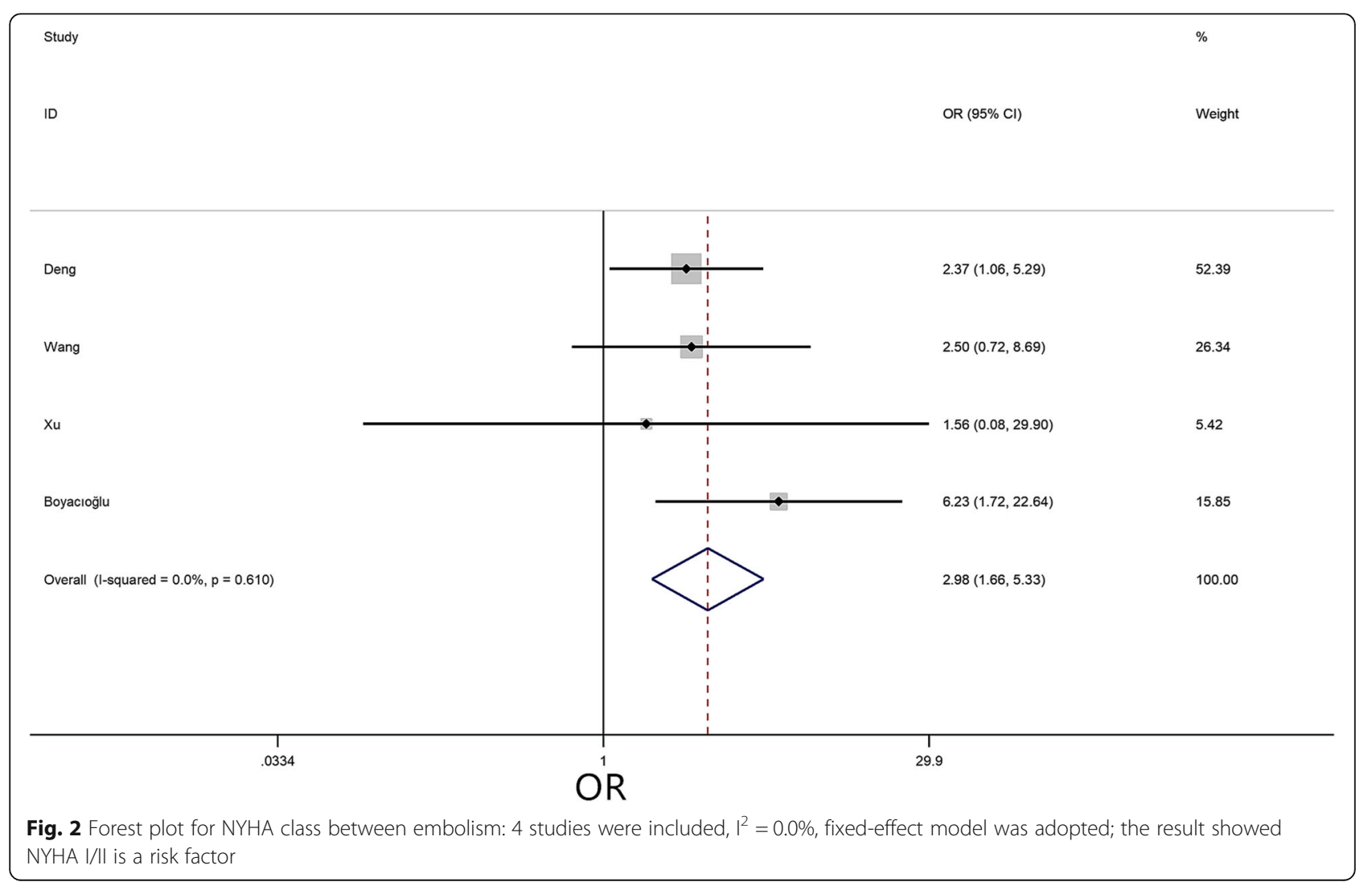




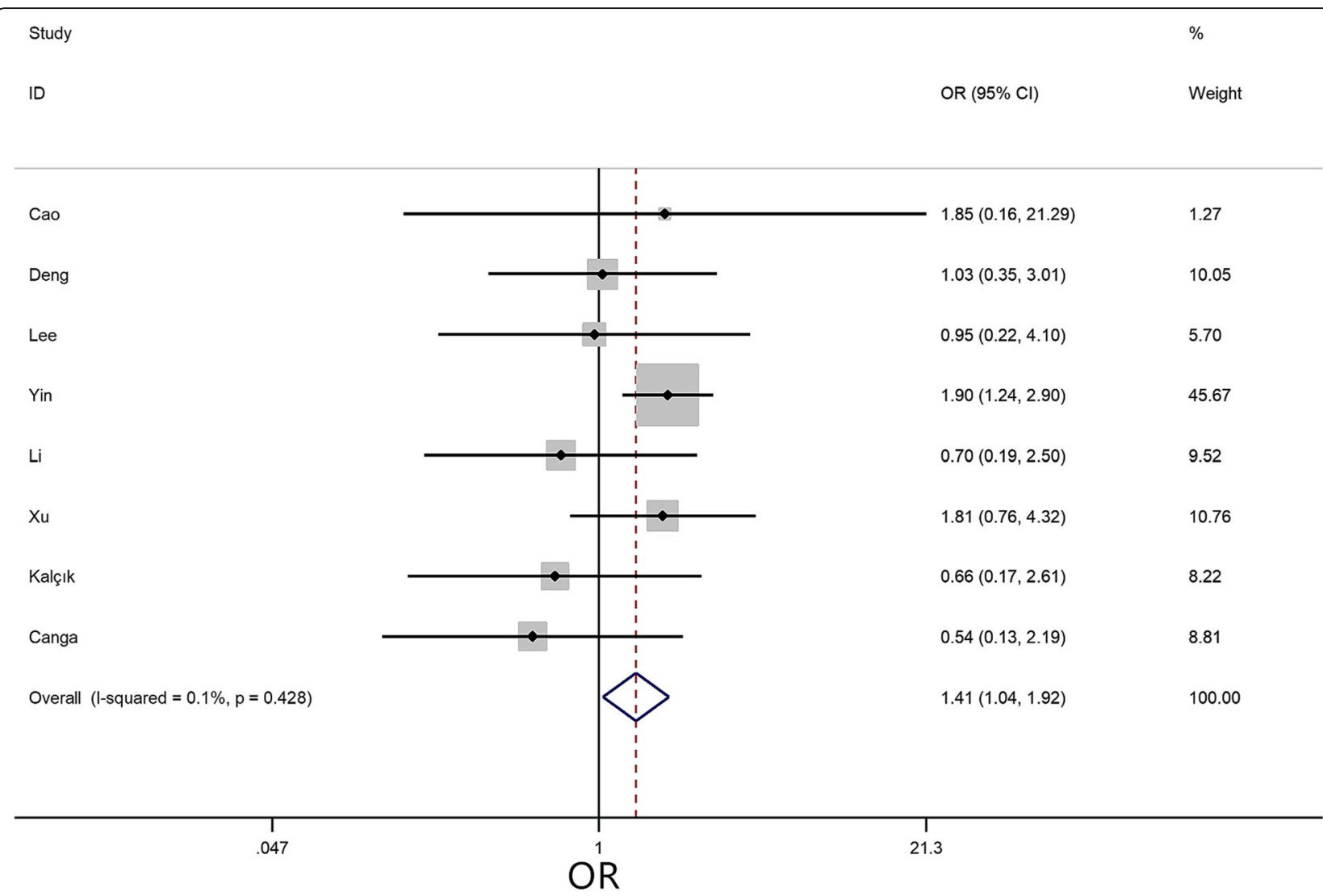

Fig. 3 Forest plot for hypertension between embolism: 8 studies were included, $I^{2}=0.1 \%$, fixed-effect model was adopted; the result showed hypertension a risk factor

shown in Fig. 1, and the main characteristics of included studies are summarized in Table 1.

\section{Meta-analysis of risk factors}

Based on the data available from the included studies, the risk factors were classified as patient characteristics, tumor characteristics, and hematological parameters in the current review. A total of 20 risk factors were individually analyzed using a fixed-effect or a random effect model to estimate the association with embolism in CM patients. The main characteristics of each risk factor are summarized in Table 2.

\section{Patient characteristics}

A meta-analysis was performed to assess the 12 risk factors, of which NYHA class (I/II) $(\mathrm{OR}=2.98,95 \% \mathrm{CI}=$ 1.66-5.33, $P<0.01)$ (Fig. 2$)$ and hypertension $(\mathrm{OR}=1.41$, $95 \% \mathrm{CI}=1.04-1.92, P=0.03$ ) (Fig. 3) significantly increased the risk of embolism in CM patients. However, no statistically significant difference was detected in the meta-analysis with respect to sex $(\mathrm{OR}=1.21,95 \% \mathrm{CI}=$ $0.96-1.53, P=0.11)$, age $(\mathrm{MD}=-0.04,95 \% \mathrm{CI}=-3.64-$ 3.56, $P=0.94)$, body mass index (BMI) $(\mathrm{MD}=1.21,95 \%$ $\mathrm{CI}=-0.43-2.84, P=0.18)$, smoking $(\mathrm{OR}=0.90,95 \% \mathrm{CI}=$
0.64-1.28, $P=0.56)$, left ventricular ejection fraction (LVEF) $(\mathrm{MD}=0.59,95 \% \mathrm{CI}=-0.20-1.38, P=0.14)$, diabetes $(\mathrm{OR}=1.32,95 \% \mathrm{CI}=0.89-1.94, P=0.16)$, hyperlipidemia $(\mathrm{OR}=0.99,95 \% \mathrm{CI}=0.53-1.85, \quad P=0.96)$, AF $(\mathrm{OR}=1.25,95 \% \mathrm{CI}=0.88-1.80, P=0.22)$, valvular heart disease $(\mathrm{OR}=0.76,95 \% \mathrm{CI}=0.41-1.40, P=0.38)$, and coronary heart disease $(\mathrm{OR}=0.99,95 \% \mathrm{CI}=-0.87-2.85$, $P=0.32$ ).

\section{Tumor characteristics}

A meta-analysis was performed for 4 risk factors. Of these, irregular tumor surface $(\mathrm{OR}=3.99,95 \% \mathrm{CI}=$ 3.04-5.25, $P<0.01$ ) (Fig. 4), atypical location $(\mathrm{OR}=$ 1.81, 95\% $\mathrm{CI}=1.13-2.88, P=0.01$ ) (Fig. 5), and narrow base $(\mathrm{MD}=-0.36,95 \% \mathrm{CI}=-0.51--0.22, P<0.01)$ (Fig. 6) significantly increased the risk of embolism in $\mathrm{CM}$ patients, while tumor size $(\mathrm{MD}=-0.10,95 \% \mathrm{CI}=$ -0.76-0.57, $P=0.78$ ) was not associated with the condition.

\section{Hematological parameters}

A meta-analysis was performed for 4 risk factors. Of these, increased fibrinogen (FIB) $(\mathrm{MD}=0.62,95 \% \mathrm{CI}=$ $0.28-0.95, P<0.01$ ) (Fig. 7) significantly increased the 


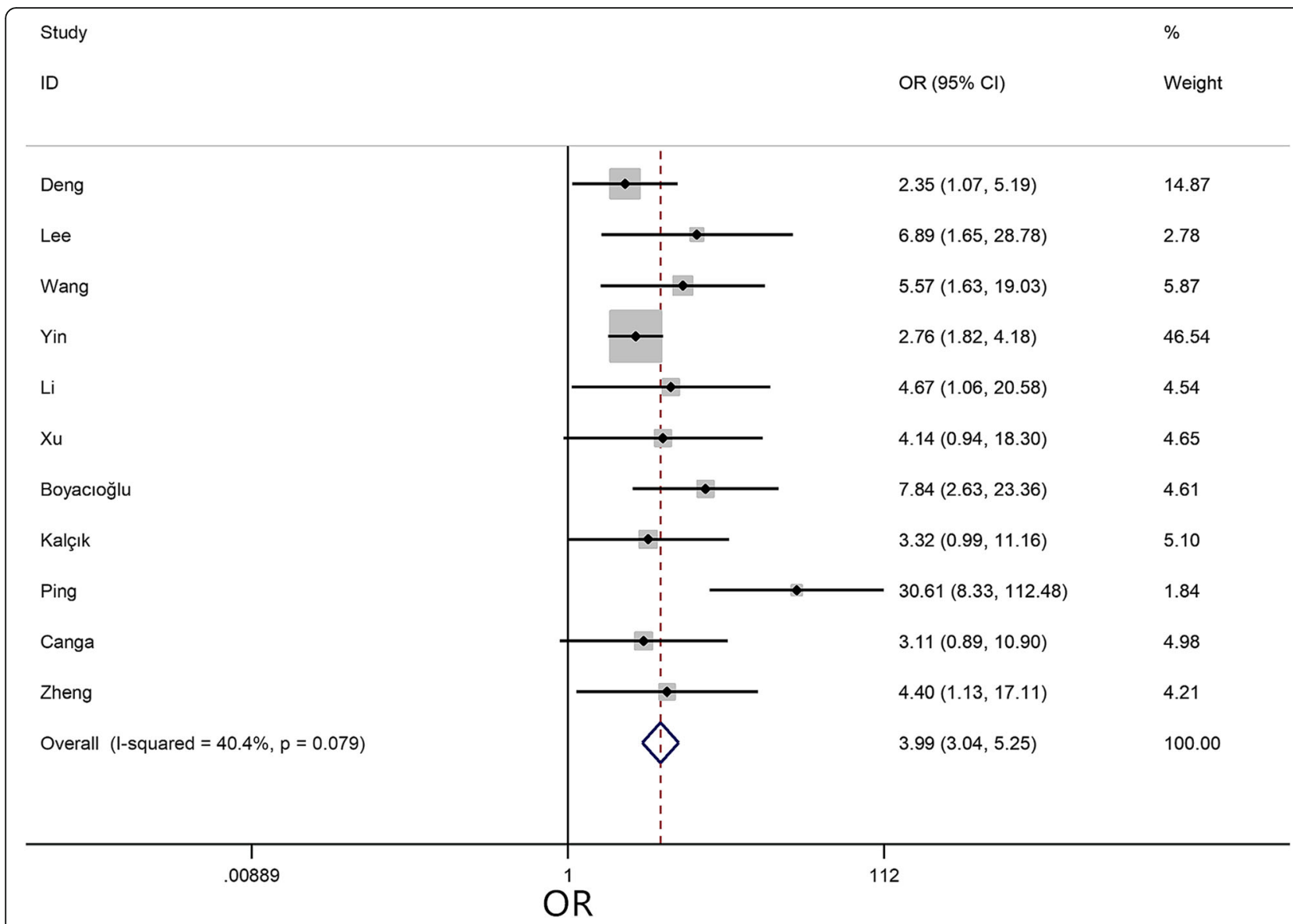

Fig. 4 Forest plot for tumor surface between embolism: 11 studies were included, $I^{2}=40.4 \%$, fixed-effect model was adopted; the result showed irregular surface is a risk factor

risk of embolism in $\mathrm{CM}$ patients, while no statistically significant difference was detected in the meta-analysis with respect to PLT $(\mathrm{MD}=9.95,95 \% \mathrm{CI}=-6.02-25.91$, $P=0.22)$, WBC $(\mathrm{MD}=0.18,95 \% \mathrm{CI}=-0.33-0.68, P=$ $0.49)$, and hemoglobin $(\mathrm{HB})(\mathrm{MD}=1.65,95 \% \mathrm{CI}=-2.91-$ 6.21, $P=0.48)$.

\section{Sensitivity analysis}

High heterogeneity across studies was detected regarding age $\left(\mathrm{I}^{2}=76.8 \%\right)$, BMI $\left(\mathrm{I}^{2}=83.7 \%\right)$, and coronary heart disease $\left(\mathrm{I}^{2}=84.2 \%\right)$. Sensitivity analysis showed a similar trend among various studies except for the study by Yin et al. [9]. After the exclusion of Yin's study, the amongstudy heterogeneity was not detected (all $\mathrm{I}^{2}=0.00 \%$, all $P>0.05)$; also, the overall effect did not differ significantly (all $P>0.05$ ).

In addition, tumor size had high heterogeneity $\left(\mathrm{I}^{2}=\right.$ 83.3\%), and sensitivity analysis showed a similar trend among studies except for the study by Kalçık et al. [13]. After this study was excluded, the among-study heterogeneity was found to be moderate $\left(\mathrm{I}^{2}=58.6 \%, P=0.03\right)$, while the overall effect did not differ significantly $(P=$ $0.19)$.

\section{Publication bias}

General considerations suggest that use of the Egger's test with substantially fewer 10 studies would be unwise [22]; hence, the publication bias was assessed for sex and tumor surface. The Egger's test not detect any publication bias on sex $(P=0.096)$ and tumor surface $(P=$ 0.051).

\section{Discussion}

In the current meta-analysis, a total of 20 potential factors were studied. The results suggested that the NYHA class, hypertension, tumor surface, tumor location, tumor base size, and FIB were independent risk factors associated with embolism.

Among patient characteristics, we found that 2/12 factors (NYHA class and hypertension) were significantly associated with embolism. The NYHA class is the most commonly used indicator of clinical response to cardiac function. The current study showed that better cardiac 


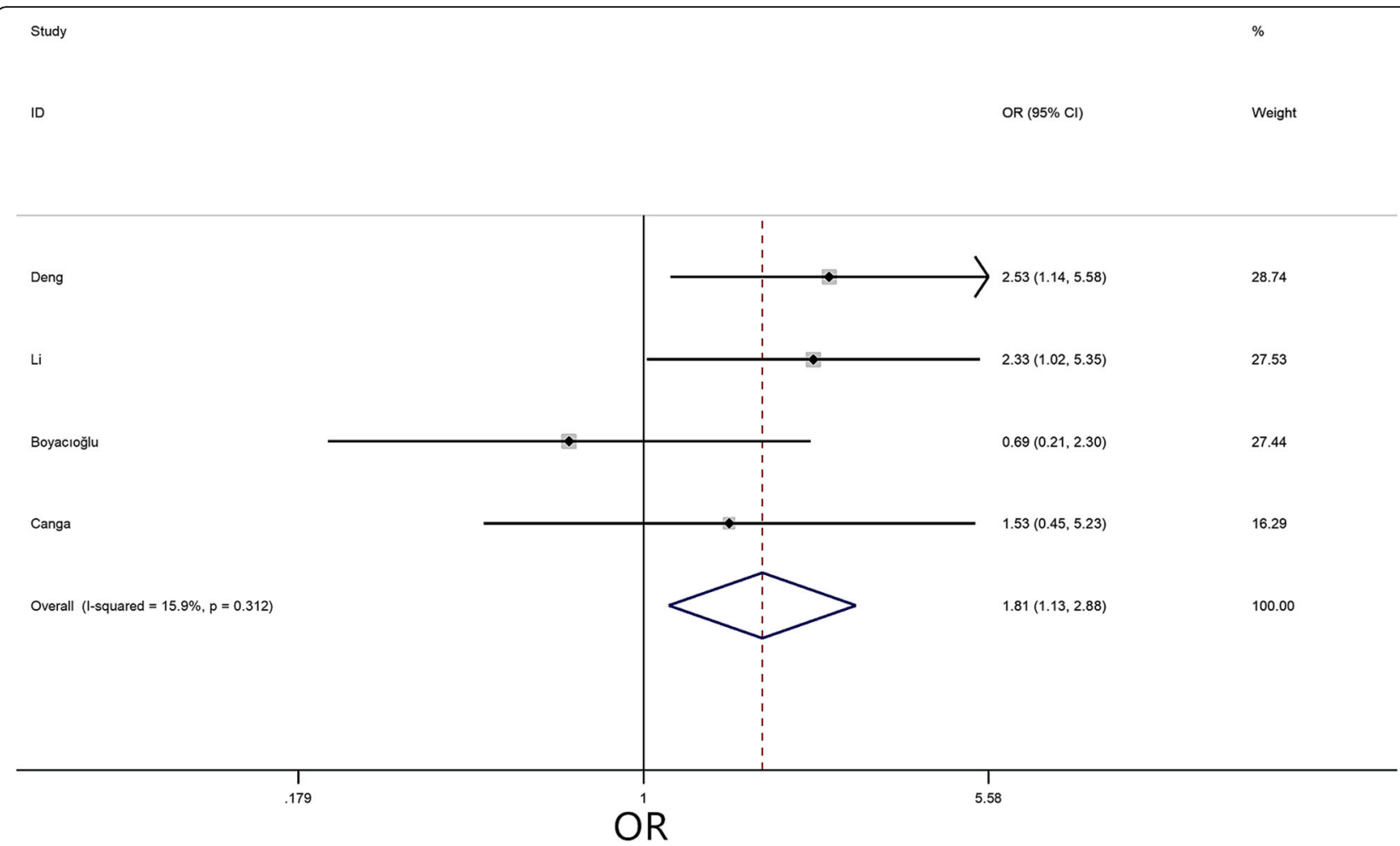

Fig. 5 Forest plot for tumor location between embolism: 4 studies were included, $I^{2}=15.9 \%$, fixed-effect model was adopted; the result showed atypical location is a risk factor

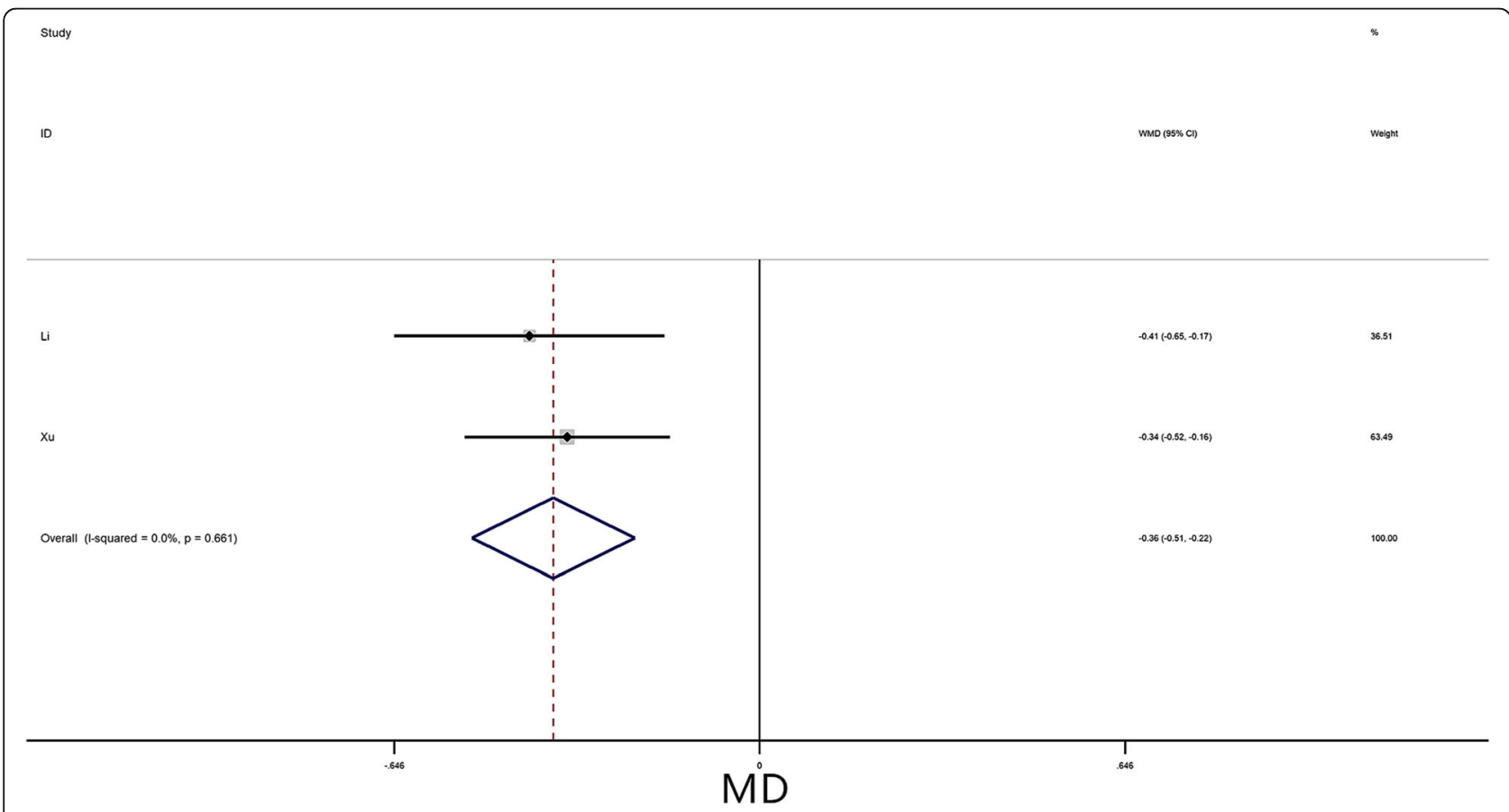

Fig. 6 Forest plot for tumor base size between embolism: 2 studies were included, $I^{2}=0.0 \%$, fixed-effect model was adopted; the result showed narrow base is a risk factor 


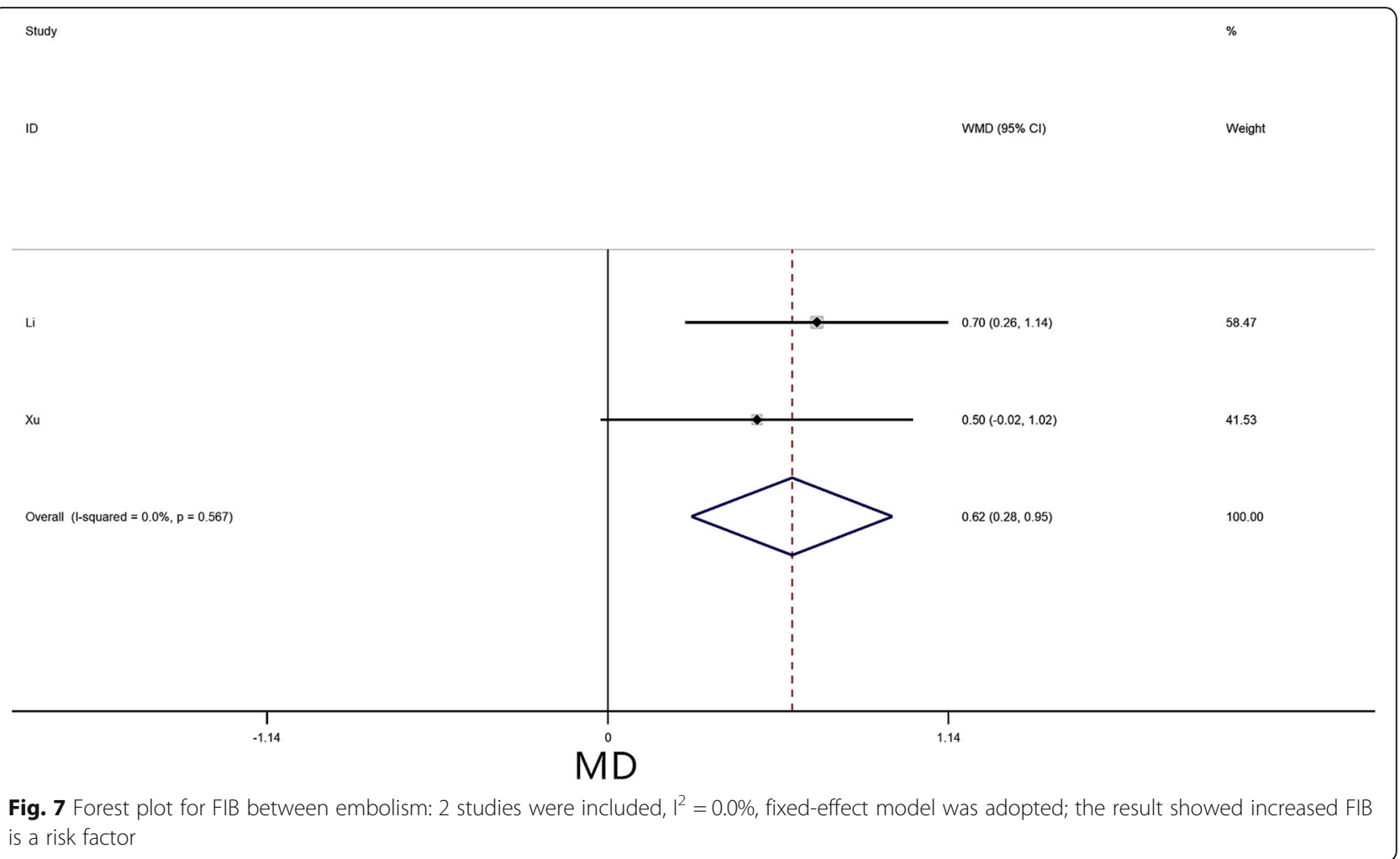

function (class I/II) was at a significantly higher risk of embolism than the worse function (class III/IV). This finding might be attributed to the fact that most embolic group patients were diagnosed after an acute embolic event; also, the tumor blockage symptoms were relatively less, and the overall cardiac function was better than that of non-embolic group. Conversely, the non-embolic group patients have a prolonged course of the disease and are likely to show hemodynamic changes; this phenomenon was associated with obstructive heart failure. However, the LVEF was not associated with embolism. We think this difference may attribute to the fact that some patients exist heart failure with preserved ejection fraction, and they also could reach NYHA class III/IV [23]. Hence, additional quantitative research about cardiac function is imperative. Some studies reported that hypertension might be a major risk factor of deep venous thromboembolism [24, 25]. Interestingly, the present study found that hypertension also was a risk factor of embolism in CM patients, which could be because high blood pressure increases the activity of PLT, making the blood hypercoagulable [26].

Regarding tumor characteristics, we found that three factors are related to embolism: tumor surface, location, and base. Macroscopically, the surface of the tumor is classified into two types [27, 28] as follows: Type 1 is characterized by an irregular surface and soft consistency, while type 2 presents a regular surface and compact consistency. Consistent with the previous studies [29-31], the current study found that embolic events are often associated with type 1 myxoma. This correlation might occur because the type 1 myxoma is prone to be friable, which leads to the shedding of tumor fragments into the bloodstream [13]. In addition, we found that atypical location is a risk factor of embolism. This conclusion is consistent with the result of the study by Deng et al. [6]. Thus, we hypothesized that the atypical location plays a significant role in hemodynamics than typical location. Lastly, the narrow tumor base was also a risk factor in this study owing to its great mobility, which tends to generate fragments [11].

In terms of hematological parameters, the present study designated increased FIB as a risk factor of embolism. It is a substrate for thrombin and is directly involved in the clotting process. In addition, FIB promotes the aggregation of PLT, increases blood viscosity, and aggravates red blood cell adhesion, all of which promote thrombosis [32]. Thus, we inferred that increased FIB promotes thrombosis on the surface of $\mathrm{CM}$, which contributes to embolism.

To the best of our knowledge, this is the first metaanalysis to investigate the risk factors of embolism in patients with $\mathrm{CM}$, with some practical clinical implications. Nevertheless, this meta-analysis also has some limitations. First, since all enrolled studies were retrospective case series, residual confounders and unidentified factors 
were inevitable in observational studies. Second, all the included studies originated from Asia, which might lead to selection bias. Third, the number of overlapped risk factors in each of the studies was small for a comprehensive statistical analysis. Finally, with respect to the tumor size, the data of our meta-analysis showed high heterogeneity. Although one major source of heterogeneity was detected by sensitivity analysis, other differences between the studies should be considered.

\section{Conclusions}

This systematic review and meta-analysis identified the following significant risk factors of embolism for CM patients: NYHA class I/II, hypertension, irregular tumor surface, atypical tumor location, the narrow base of tumor, and increased FIB. For CM patients with these factors, early surgery may be beneficial for preventing embolism.

\section{Supplementary information}

Supplementary information accompanies this paper at https://doi.org/10. 1186/s12872-020-01631-w.

Additional file 1.

Additional file 2.

Additional file 3.

\section{Abbreviations}

CM: Cardiac myxoma; OR: Odds ratio; MD: Mean difference; Cl: Confidence interval; NYHA: New York heart association; FIB: Fibrinogen; BMI: Body mass index; LVEF: Left ventricular ejection fraction; AF: Atrial fibrillation;

PLT: Platelet count; WBC: White blood cells; HB: Hemoglobin

\section{Acknowledgments}

Not applicable

\section{Authors' contributions}

L.G gave his substantial contribution to the conception of the work. L. P, J. W, L. G and Y. L contributed to the study design. L. P wrote the draft of the manuscript. J. $W$ and $Y$. $L$ revised it critically for intellectual content. $Y . L$ revised the manuscript. All authors approved the final version of the manuscript.

\section{Funding}

Not applicable.

\section{Availability of data and materials}

The datasets used and/or analyzed during the current study are available from the corresponding author on reasonable request.

\section{Ethics approval and consent to participate}

Not applicable.

\section{Consent for publication}

Not applicable.

\section{Competing interests}

The authors declare that they have no competing interests.
Received: 23 November 2019 Accepted: 20 July 2020

Published online: 25 July 2020

\section{References}

1. Dias RR, Fernandes F, Ramires FJA, Mady C, Albuquerque CP, Jatene FB. Mortality and embolic potential of cardiac tumors. Arq Bras Cardiol. 2014; 103(1):13-8.

2. Yuan SM, Humuruola G. Stroke of a cardiac myxoma origin. Rev Bras Cir Cardiovasc. 2015;30(2):225-34.

3. Wang QS, Yang FF, Zhu F, Yao CS. A case report of left atrial myxomainduced acute myocardial infarction and successive stroke. Medicine (Baltimore). 2018;97(51):e13451.

4. Cianciulli TF, Cozzarin A, Soumoulou JB, Saccheri MC, Mendeze RJ, Beck MA, et al. Twenty years of clinical experience with cardiac myxomas: diagnosis, treatment, and follow up. J Cardiovasc Imaging. 2019;27(1):37-47.

5. Cao GF, Bi Q, Cao L, Wang C. The clinical characteristics of stroke in young patients with cardiac myxoma. Chin J Intern Med. 2017:56(4):263-7.

6. He DK, Zhang YF, Liang Y, Ye SX, Wang C, Kang B, et al. Risk factors for embolism in cardiac myxoma: a retrospective analysis. Med Sci Monit. 2015; 21:1146-54.

7. Lee SJ, Kim JH, Na CY, Oh SS. Eleven years' experience with Korean cardiac myxoma patients: focus on embolic complications. Cerebrovascular Dis. 2012;33(5):471-9.

8. Wang ZJ, Chen SQ, Zhu M, Zhang H, Li HX, Yuan GD, et al. Risk prediction for emboli and recurrence of primary cardiac myxomas after resection. J Cardiothorac Surg. 2016;11:22.

9. Yin L, Wang J, Li W, Ling XY, Xue Q, Zhang YF, et al. Usefulness of CHA2DS2-VASC scoring systems for predicting risk of perioperative embolism in patients of cardiac myxomas underwent surgical treatment. Sci Rep. 2016:6:39323.

10. Xu R. Analysis of risk factors for vascular embolization of cardiac myxoma [master's thesis]. Nanning (GX): Guangxi Medical University; 2018. p. 45.

11. Xu GX. Risk assessment of vascular embolization of cardiac myxoma [dissertation]. Hangzhou (ZJ): Zhejiang University; 2016. p. 80.

12. Boyacıoğlu K, Kalender M, Dönmez AA, Çayhan B, Tuncer MA. Outcomes following embolization in patients with cardiac myxoma. J Card Surg. 2017; 32(10):621-6.

13. Kalçık M, Bayam E, Güner A, Küp A, Kalkan S, Yesin M, et al. Evaluation of the potential predictors of embolism in patients with left atrial myxoma. Echocardiography. 2019;36(5):837-43.

14. Ping LY, Ying K, Xiong YP, Zhang CQ, Liu YN, Guo LY. Echocardiography in predicting the risk of embolism in atrial myxoma. Chin J Ultrasound Med. 2019;35(9):799-802.

15. Canga Y, Karataş MB, Calık AN, Tanik VO. Cardiac myxoma: fourteen-year experience of a tertiary reference center. Kosuyolu Heart J. 2017;20(3):210-6.

16. Zheng Z, Guo GJ, Xu L, Lei L, Wei X, Pan YM. Left atrial myxoma with versus without cerebral embolism: length of symptoms, morphologic characteristics, and outcomes. Tex Heart Inst J. 2014;41(6):592-5.

17. Elbardissi AW, Dearani JA, Daly RC, Mullany CJ, Orszulak TA, Puga FJ, et al. Embolic potential of cardiac tumors and outcome after resection. Stroke. 2009;40(1):156-62

18. Pinede $L$, Duhaut $P$, Lorie R. Clinical presentation of left atrial cardiac myxoma a series of 112 consecutive cases. Medicine (Baltimore). 2001;80(3): 159-72.

19. Moher D, Liberati A, Tetzlaff J, Altman DG, PRISMA group. Preferred reporting items for systematic reviews and meta-analyses: the PRISMA statement. Open Med. 2009;3(2):123-30.

20. Vaideeswar P, Gupta R, Mishra P, Lanjewar C, Raut A. Atypical cardiac myxomas: a clinicopathologic analysis and their comparison to 64 typical myxomas. Cardiovasc Pathol. 2012;21(3):180-7.

21. Moola S, Munn Z, Tufanaru C, Aromataris E, Sears K, Sfetcu R, et al. Chapter 7: systematic reviews of etiology and risk. In: Aromataris E, Munn Z, editors. Joanna Briggs Institute Reviewer's Manual: The Joanna Briggs Institute; 2017. Available from https://reviewersmanual.joannabriggs.org/.

22. Sterne JAC, Sutton AJ, Loannidis JPA, Terrin N, Jones DR, Lau J, et al. Recommendations for examining and interpreting funnel plot asymmetry in meta-analyses of randomised controlled trials. BMJ. 2011;343:d4002.

23. Dalos D, Mascherbauer J, Zotter-Tufaro C, Duca F, Kammerlander AA, Aschauer $\mathrm{S}$, et al. Functional status, pulmonary artery pressure, and clinical outcomes in heart failure with preserved ejection fraction. J Am Coll Cardiol. 2016;68(2):189-98 
24. Yang SD, Liu H, Sun YP, Yang DL, Shen Y, Feng SQ, et al. Prevalence and risk factors of deep vein thrombosis in patients after spine surgery: a retrospective case-cohort study. Sci Rep. 2015;5:11834.

25. Huang L, Li J, Jiang Y. Association between hypertension and deep vein thrombosis after orthopedic surgery: a meta-analysis. Eur J Med Res. 2016; 21:13.

26. Long JJ, Zhao AT, Liu J, Luo BQ. Relationship between hypercoagulability and insulin resistance in patients with essential hypertension. Chin J Hemorh. 2004;14(2):186-8.

27. Swartz MF, Lutz CJ, Chandan VS, Landas S, Fink GW. Atrial myxomas: pathologic types, tumor location, and presenting symptoms. J Card Surg. 2006;21(4):435-40.

28. Jain S, Maleszewski JJ, Stephenson CR, Klarich KW. Current diagnosis and management of cardiac myxomas. Expert Rev Cardiovasc Ther. 2015;13(4): 369-75.

29. Ha JW, Kang WC, Chung N, Chang BC, Rim SJ, Kwon JW, et al. Echocardiographic and morphologic characteristics of left atrial myxoma and their relation to systemic embolism. Am J Cardiol. 1999;83(11):1579-82.

30. Orlandi A, Ciucci A, Ferlosio A, Pellegrino A, Chiariello LG, Spagnoli LG, et al. Increased expression and activity of matrix metalloproteinases characterize embolic cardiac myxomas. Am J Pathol. 2005;166(6):1619-28.

31. Yu L, Gu TX, Shi EY. Echocardiographic findings and clinical correlation with cardiac myxoma. JACC Cardiovasc Imaging. 2016;9(5):618-21.

32. Drouet $L$, Sollier CBD. Is fibrinogen a predictor or a marker of the risk of cardiovascular events. Therapie. 2005;60(2):125-36.

\section{Publisher's Note}

Springer Nature remains neutral with regard to jurisdictional claims in published maps and institutional affiliations.

Ready to submit your research? Choose BMC and benefit from:

- fast, convenient online submission

- thorough peer review by experienced researchers in your field

- rapid publication on acceptance

- support for research data, including large and complex data types

- gold Open Access which fosters wider collaboration and increased citations

- maximum visibility for your research: over $100 \mathrm{M}$ website views per year

At BMC, research is always in progress.

Learn more biomedcentral.com/submissions 